\title{
Research on the Reform of Talent Cultivation Program of Physical Education
}

\author{
Dong Jiang \\ Yulin University, Shaanxi, Yulin, China, 719000
}

Keywords: Reform, Talent Cultivation Program, Physical Education

\begin{abstract}
In order to realize the strategic goal of "rejuvenating the country through science and education", the Ministry of Education has carried out the reform of basic education curriculum as the core link of the talent quality training project and since the beginning of the year, the basic education curriculum reform has been carried out nationwide. The traditional linear, closed curriculum and teaching design paradigm has been more and more questioned, multi-perspective, multi-dimensional focus on student-oriented learning curriculum and teaching design paradigm continue to produce. In order to meet the needs of basic education curriculum reform, the Ministry of Education "Basic Education Curriculum Reform" clearly stipulates that "normal colleges and other basic education teachers to undertake the training and training tasks of higher education institutions and training institutions should be based on basic education curriculum reform objectives and content adjustment objectives, professional settings and curriculum structure, reform teaching methods.
\end{abstract}

\section{Introduction}

With the rapid development of the economy, the increasing progress of social civilization, the increasing importance of health for human beings, the importance of sports awareness is more prominent. Especially the popularization of mass sports, recreational sports, lifelong sports and lifelong education in the international field, make sports become a way of life rather than just the concept of curriculum quietly rising, school physical education has undergone tremendous changes. In its special report, UNESCO said, "In the final analysis, the most successful workers in the 21st century will be people who are fully developed and open to new ideas and new opportunities." The American Commission for Teaching Quality "The development of excellence is the education and training of new generation of teachers is to ensure that the United States leading position to ensure the survival of the United States and people living conditions." "China Education Reform and Development Program" that "today's world political situation, the international Competition is becoming increasingly fierce, rapid development of science and technology. World-wide economic competition, comprehensive national strength competition, essence is science and technology competition and national quality competition. "' Revitalize the nation's hope in education and revitalize the hope of education in teachers ". The "Renaissance of Science Education", which originated in the United States in the middle of the century has promoted the curriculum reform of education in all developed countries. In particular, the reform of basic education since the 1980s has brought a series of physical education curriculum reform to the western developed countries, Countries have introduced a new school physical education curriculum standards or teaching syllabus, to school sports has brought infinite vitality.

\section{The Main Problems in the Curriculum System of Physical Education Major in Chinese Universities}

Heavy technology, light foundation, light discipline highlighted in the teaching of surgery. Teaching to highlight its competitive, teachers focus on technical skills, skills, teaching, despise the cultivation of practical ability, especially in the promotion of teacher education in the cultivation of 
high-quality citizens under the premise of a primary and secondary school teachers as a training concept of education has not been reflected, university education, general education and comprehensive ability to improve that people's basic quality has not been taken seriously. The survey shows that the number of hours of the course is generally higher than the recommended number of hours of the course program. The setting of the course has lagged behind the needs of the market. Many of the sports programs that have been formed or will form a professional need did not set up. The proportion of subjects and disciplines is far from reasonable and cannot meet the needs of students' lifelong learning. Many schools do not strengthen the development of special courses, local courses and school-based curriculum according to school characteristics and local social needs.

In the teaching of college physical education, regardless of theoretical courses or technical teaching, or the traditional "impartial" teaching-based, student's learning almost became a passive acceptance, so the enthusiasm and creativity of students have not been the largest limit the play and upgrade. In the basic education and health curriculum reform, a variety of new teaching methods have long been used in the classroom. Student development is the starting point and end of the work of physical education teachers, physical education teachers should help students in the process of development to achieve their own professional development. In the teaching of physical education in colleges and universities, there is a tendency to neglect the students and students 'research. The curriculum of teachers' education does not reflect the new requirements of social progress to students 'development, and the latest achievements of students' research are not better in the curriculum To be reflected in the teaching should also be through a variety of ways to close, observe, listen, study students, learn to respect students, understand students, love students, to promote each student a comprehensive and personality development. Such as situational teaching, autonomy, cooperation, inquiry teaching, the students as active participation in learning the subject has become the basic education curriculum reform paradigm shift one of the important content.

The survey shows that the colleges and universities in the teaching of the prevalence of curriculum design and emphasizes the vertical depth of professional education, compulsory courses and more attention to the phenomenon. Compulsory courses and elective courses are not coordinated, compulsory courses in the proportion of the total number of courses is much higher than the proportion of elective courses. Therefore, it is necessary to make the development of students' personality and interest, and to cultivate innovative talents. The total number of courses offered by the United States, Japan's Sports University and the Department of Physical Education is about twice that of our country. The proportion of compulsory and elective courses is different. In general, the elective courses are larger than the required courses. This is also a worthy aspect of the reform of the curriculum reform of college physical education.

\section{Requirements of Personnel Training in Physical Education in Colleges and Universities}

The curriculum goal of basic education curriculum reform transcends the knowledge and skills orientation, so that students acquire knowledge and skills while learning to learn and form the correct values, it is knowledge and skills, processes and methods, emotional attitudes and values of the three truly unified, the health value of the course. The implementation of quality education makes the basic education of education, education, training objectives, school mode, curriculum, teaching materials and many other aspects must change. With the development of the times, the current "ordinary college physical education undergraduate program" and the basic education of physical education curriculum reform has become increasingly prominent. Therefore, the curriculum reform of physical education in colleges and universities cannot simply follow the concept of "undergraduate program of physical education in ordinary colleges and universities", but rather according to the specific requirements of the reform of basic education and health curriculum reform.

Basic education curriculum reform physical education curriculum standard instead of the original "syllabus", that is, the vast majority of students concerned about the learning process and the results rather than the specific provisions of the teaching content, especially the curriculum standards 
adhere to the target content, from the emphasis on teaching materials to this factor emphasizing the integration of teachers, students, teaching materials, environment and other factors, that teachers are not textbooks, negative professors, but the active design of teaching programs. This puts forward new requirements for the original curriculum and teaching contents and teaching methods of physical education in colleges and universities.

To the "health first" as the guiding ideology of the basic education of sports and health curriculum education system to establish the traditional competitive education technology-based curriculum system is a great challenge, which also inevitably lead to teaching content and curriculum system comprehensive reform. This put the reform of college physical education professional training to the development of the front. The reform of sports and health curriculum in primary and secondary schools will be difficult to be sustained. If the reform of PE and health curriculum in primary and secondary schools is carried out, the curriculum reform of physical education should also be lost. This study focuses on the current situation of the cultivation of college physical education talents from the perspective of sports and health curriculum reform, which is the need of education and the need of reform. In summary, domestic and foreign research of sports education professionals training literature review, this research has important reference value. At present, although some of the combination of basic education curriculum reform under the sports and health curriculum standards for college sports education professionals training research, but not enough, research is not deep, at the same time, Chinese colleges and universities take the initiative to adapt to the requirements of sports and health curriculum standards. The reform of the training of physical education talents is not enough, neither extensive nor deep, so it is possible and necessary for the further study of this study.

\section{Effective Mode of Personnel Training in Physical Education}

The openness and non-orientation of the personnel training mode of foreign sports institutes not only provide the opportunity for teachers to become non-education graduates, but also ensure the teachers' team is relatively stable in quantity and quality, and is conducive to normal education Supply and demand changes to make rapid response to meet the needs of socio - economic and cultural development. Therefore, in order to cultivate the needs of the basic education curriculum reform of physical education teachers, especially the development of society on the sports people's demand for diversification will inevitably lead to the diversification of teacher training model. Breaking the past, a single training model is imperative. Not only to social needs, discipline system and student development as the pillar to build the basic framework of personnel training model, from the curriculum structure, teaching content, curriculum, student knowledge structure, starting as the basis for the development of training model.

In order to change the training of college physical education talents in our country, it lags behind the demand of basic education curriculum reform, lacks the advancement, establishes the integration of pre - service and post - vocational education of PE teacher education, and becomes the urgent task of cultivating physical education talents in colleges and universities. Specific measures are as follows in the training objectives, to the comprehensive university mixed set the direction of development, training compound sports education talents, the establishment of multiple training model. In the training institutions, the reorganization of the normal colleges and universities, the establishment of the Institute of Education, is responsible for the pre-vocational and post-vocational education effective convergence, the establishment of a unified and coordinated leadership system, the formation of the combination of internal and external, internal and external communication of the establishment of physical education network Integration of physical education teachers. In the course content, the college physical education professional personnel training should focus on the basic quality of teachers to develop education, attention to "whole people" education, including humanistic spirit, scientific spirit, innovative spirit training is the basic discipline of solid grasp, especially professional basic knowledge and basic skills, strengthen the practice of education, so that students will not only explain the training, will demonstrate, will teach again, pay attention to the cultivation of educational research ability, it is a strong guarantee for the 
continuous development of physical education teachers.

Physical education departments to strengthen the contact with the employment unit, that is, physical education departments and employers to choose the physical education students or by the employment unit to select the physical education students to train, by the University and the relevant employer to develop standards based on the joint development of sports Education students to assess and evaluation. Strengthen the future of physical education teachers during the University of education practice and comprehensive quality training, adhere to the combination of theory and practice to change the current university-based physical education teacher training model, targeted and timeliness, the real use of units and college physical education Talent training to establish a relationship between equality and cooperation. The students who develop physical education are based on the promotion of comprehensive literacy and strictly stipulate the requirements. After graduating from the requirements, the school will award the degree and academic qualification certificates for the employing units to identify and arrange suitable work or formulate continuous training programs. And the post-training and in-school textual research closely, to strengthen the mutual promotion between each other, mutual feedback for the century sports education reform and development to provide protection. Such as the practice of South China Normal University is worth promoting, the implementation of teachers vocational skills certification system, students do not get a certificate cannot participate in educational practice, a strong impetus to the implementation of teachers skills. From the teaching management system in the world, the higher education system with credit system shows an upward trend, which shows that the credit system is fully capable of cultivating high-quality compound talents with its flexibility. With the domestic demand for talent in the diversified development, especially the curriculum development more and more miniaturization, individualization, only the real implementation of the credit system, in order to make good talent, the competition mechanism into teaching management, promote teaching and learning to promote teaching content, teaching methods to improve. Therefore, it is imperative to actively explore the new PE teaching management system.

\section{Conclusion}

The training of college physical education talents generally lags behind the reform of basic education and health curriculum, which must be paid great attention and attention. Sports and health curriculum reform makes the physical education teachers must move towards the professional development of teachers, college physical education professional personnel training must be "teacher education" to "teacher education" development. The goal of college physical education professional training should keep pace with the times, close to the reality of basic education, fully embody the mastery of educational theory, the cultivation of teachers' quality and the requirement of individualized development, and strive to improve the market competitiveness of talents cultivated in college physical education. The improvement of the training mode of physical education specialty in colleges and universities should start from the aspects of training objectives, curriculum, curriculum structure, curriculum management and teaching practice. To adapt to the basic education curriculum reform to establish the "health first" guiding ideology, college physical education curriculum should be such as health education, sports science research methods in the future primary and secondary physical education teachers work very practical curriculum should be included in the main course.

\section{Acknowledgements}

Fund Project: Yulin college professional talent training scheme reform research project in 2017(TJG1751) 


\section{References}

[1] Hu Dantao. Ordinary college students of physical education smoking behavior analysis[J]. Sports. 2017 (12)

[2] Xue Lan, Jin Saiying, Jiang Zheting, Li Qidi. Zhu Guangqian Physical education view and its enlightenment[J]. Journal of Beijing Sport University. 2017 (08)

[3] Duan Shengcai. Locke physical education in the humanistic thinking[J]. Zhejiang Sports Science. 2017 (05)

[4] Qiao Liang. On the mode and method of physical education teaching[J]. Occupation. 2017 (24)

[5] Liu Ri-liang.Study on the Innovation of Talents Training Model of Physical Education under the Background of New Situation [J]. Sports World. 2017 (11)

[6] Li Zhiming. Physical education based on physical perspective and its value [J]. Sports world.) 2017 (11) 